\title{
Characterization of Bacillus thuringiensis isolates toxic to cotton boll weevil (Anthonomus grandis)
}

\author{
Érica Soares Martins ${ }^{\text {a }}$, Lílian Botelho Praça a, Vinícius Fiúza Dumas a, \\ Joseilde O. Silva-Werneck ${ }^{a}$, Eduardo Hideki Sone ${ }^{\text {a }}$, Isabel C. Waga ${ }^{a}$, Colin Berry ${ }^{b}$, \\ Rose Gomes Monnerat ${ }^{\mathrm{a}, *}$ \\ ${ }^{a}$ Embrapa Recursos Genéticos e Biotecnologia, SAIN-Parque Rural, Caixa postal 02372, 70770-900-Brasilia-DF, Brazil \\ ${ }^{\mathrm{b}}$ Cardiff School of Biosciences, Cardiff University, Museum Avenue, Cardiff CF10 3US, Wales, UK
}

Received 6 April 2006; accepted 15 September 2006

Available online 27 September 2006

\begin{abstract}
The cotton boll weevil (Anthonomus grandis) is the major cotton pest in the Americas. One of the alternatives for its control is the utilization of Bacillus thuringiensis (Bt), an entomopathogenic bacterium characterized by its production of insecticidal crystal proteins. Embrapa Genetic Resources and Biotechnology has a collection of Bacilli in which different isolates of $B t$ are stored. A method for rearing and maintenance of Anthonomus grandis on artificial diet in the laboratory was developed, and a robust larval bioassay protocol was established for the selection of B. thuringiensis isolates toxic to boll weevil. After preliminary bioassays performed with 215 isolates, 5 were selected that demonstrated a good level of toxicity and these were analyzed in more detail. The most toxic were S601 and S1806 presenting $\mathrm{LC}_{50}$ (lethal concentration to kill $50 \%$ if the larvae) of $0.14 \mathrm{mg} / \mathrm{ml}$ and $0.30 \mathrm{mg} / \mathrm{ml}$, respectively. S601 showed an $\mathrm{LC}_{50}$ value that was half that of the standard B. thuringiensis subspecies tenebrionis and S1806 demonstrated similar values of LC ${ }_{50}$ to the standard. S601 contained the $\operatorname{cry} 1 B$ gene and $\mathrm{S} 1806$ had the cry $4 A$, cry $4 B$, cry10, cry 11, cyt 1 and cyt 2 genes like B. thuringiensis subspecies israelensis. (C) 2006 Elsevier Inc. All rights reserved.
\end{abstract}

Keywords: Bacillus thuringiensis; Anthonomus grandis; Biological control; Toxicity; cry genes

\section{Introduction}

Cotton is one of the most financially profitable crops worldwide; in the 1990s its price was higher than those of other important products such as soy, corn and wheat (Ponchio, 2001). In the textile industry, the cotton fiber is recognized as one of the most important and valuable in the market. The extensive plantation of monocultures like soy, corn, cotton, canola and other plants, requires a high investment in insecticides owing to their resident pests, especially from the lepidopteran and coleopteran orders. According to Santos et al. (2003), about US\$ 3-5 billion are

\footnotetext{
* Corresponding author. Fax: +55 6134484672.

E-mail address: rose@cenargen.embrapa.br (R.G. Monnerat).
}

spent on pesticides per year, and of that US\$ 645 million are spent in cotton plantations.

Cotton boll weevil, Anthonomus grandis Boheman (Coleoptera: Curculionidae), is a significant pest of cotton production in the Americas (Busoli et al., 1994; Gallo et al., 2002). In order to decrease damage and loss of production, this pest has been controlled primarily by the use of chemical agents. However, while this has produced efficient cotton weevil control (Martin et al., 1987; Wolfenberger et al., 1997), these chemicals are expensive and may cause negative environmental impacts. Other control methods employed are the use of pheromones (Gallo et al., 2002), early budding varieties, gathering and destruction of fallen flower buds (Silvie et al., 2001), biological control (Pallini et al., 2006) and integrated pest management (Luttrell et al., 1994). In addition, there is a possibility of producing transgenic cotton containing a gene or genes to make the plant 
resistant to this insect. Transgenic cotton plants encoding a Bacillus thuringiensis Berliner protein (Bt cotton) have been adopted by farmers in Mexico and the USA to control caterpillar infestations, and this approach has contributed to a decrease in insecticide applications by $50 \%$. In Argentina, this reduction in insecticide use has reached 65\% (Santos et al., 2003).

Bacillus thuringiensis $(B t)$ is an aerobic, Gram-positive bacterium, characterized by the production of protein inclusions, called $\delta$-endotoxin or Cry proteins (Feitelson et al., 1992). To date, more than 300 cry genes have been sequenced and the Cry proteins are classified into at least 49 groups organized into subgroups according to the percentage identity of their amino acid sequences (Crickmore et al., 1998). The toxins usually described as active against insects of the order Coleoptera are those of the Cry3 and Cry8 classes (Bravo et al., 1998; Abad et al., 2001), but lately some toxins from Cry1, Cry22, Cry34 and Cry35 classes have been described as toxic to this order as well (Tailor et al., 1992; Baum and Light Mettus, 2000; Baum et al., 2004). Embrapa, Genetic Resources and Biotechnology (Cenargen) has a collection of entomopathogenic Bacillus isolates (Monnerat et al., 2001), including isolates of $B$. thuringiensis. The aim of this work was to identify the isolates of B. thuringiensis showing toxic activity to cotton boll weevil, which may be used as a source of genes to create a transgenic plant.

\section{Materials and methods}

Two hundred and fifteen isolates of $B$. thuringiensis were used from a collection of entomopathogenic Bacillus isolates of Embrapa Genetic Resources and Biotechnology. These isolates were obtained from soil and water samples from different parts of Brazil and are stored as dry spores at room temperature $\left(25^{\circ} \mathrm{C}\right)$ (Monnerat et al., 2001).

The insects chosen for the bioassays came from the Cenargen laboratory of insect breeding where the mass culture of cotton boll weevil is performed. The insects were maintained in an environmentally controlled room under the following conditions: $25^{\circ} \mathrm{C}, 60 \%$ relative humidity and a photoperiod of 12:12. Groups of up to 500 adults were maintained in a plastic cage with a mesh base (aperture size approximately $1 \mathrm{~mm}$ ), positioned over a collecting tray into which eggs and feces can fall and accumulate. The adults were fed on an artificial diet comprised of $43.5 \mathrm{~g}$ agar (Biobrás, Brazil), $60 \mathrm{~g}$ Brewer's yeast, $60 \mathrm{~g}$ wheat germ, 40 pharmamedia (Traders Protein, Memphis, Tennessee, USA), $100 \mathrm{~g}$ soy protein, $60 \mathrm{~g}$ sucrose, $10 \mathrm{~g}$ mineral salts $\left(21 \% \mathrm{CaCO}_{4}, 0.039 \% \mathrm{Cu}_{2} \mathrm{SO}_{4}, 9 \% \mathrm{MgSO}_{4}, 0.009 \% \mathrm{~K}_{2} \mathrm{SO}_{4}\right.$, $12 \% \mathrm{KCl}, 31 \% \mathrm{KH}_{2} \mathrm{PO}_{4}, 0.057 \% \mathrm{NaF}, 14.9 \% \mathrm{Ca}_{3} \mathrm{PO}, 1.47 \%$ $\mathrm{FePO}_{4}, 0.02 \% \mathrm{MnSO}_{4}, 0.009 \% \mathrm{Al}_{2}\left(\mathrm{SO}_{4}\right)_{3}, 0.005 \mathrm{KI}, 10.5 \%$ $\mathrm{NaCl}), 20 \mathrm{~g}$ ascorbic acid, $2.4 \mathrm{~g}$ sorbic acid, $2 \mathrm{~g}$ nipagim (Vetec, Rio De Janeiro, Brazil) and $10 \mathrm{ml}$ vitamin solution (1.2\% ascorbic acid, $0.03 \%$ calcium pantothenate, $0.015 \%$ niacin, 0.008 riboflavin, $0.004 \%$ thiamin $\mathrm{HCl}, 0.004 \%$ pyridoxine $\mathrm{HCl}, 0.008 \%$ ) in a total volume of 1.51 of water.
This diet was cut into blocks of $1 \times 3 \times 0.5 \mathrm{~cm}$, which were placed in the cage on top of a plastic support, approximately $1 \mathrm{~cm}$ high. Every 2 days, the eggs were collected, together with the feces, and were placed in a solution of $18 \% \mathrm{CuSO}_{4}$. In this solution, the eggs float, whereas the feces sediment. The eggs were then collected and disinfected in $0.3 \%$ benzalconium chloride and separated into petri dishes containing the above diet, in groups of approximately 60 . The eggs hatched and the larvae grew in these plates to the adult stage, when they were collected and transferred to the cage.

Two kinds of bioassays were carried out: (i) the selective or excluding one, the aim of which was to identify those isolates presenting toxic activity to the insect, that is, any which was capable of killing at least $50 \%$ of the larvae tested at a single dose; and (ii) the dose-dependent assay, the purpose of which was to quantify the toxicity of each isolate.

For selective bioassays, bacterial cultures were grown to sporulation in NYSM medium (Yousten, 1984) for $48 \mathrm{~h}$ at $28^{\circ} \mathrm{C}$ and $200 \mathrm{rpm}$ in a rotating shaker. Ten milliliter of these cultures were added to $35 \mathrm{ml}$ of the above artificial diet at about $50^{\circ} \mathrm{C}$, just before it was poured into petri dishes. As the artificial diet solidified, 15 holes of approximately $2 \mathrm{~mm}$ diameter were punched into the surface of each petri dish. One neonate larva was placed in each hole. Each assay comprised four replicates (4 petri dishes) and was repeated four times and one dish was left without bacteria, as a control. Bioassays were assessed after 7 days (Praça et al., 2004).

The isolates that killed more than $50 \%$ of the larvae in the selective bioassays were lyophilized after being cultivated for $72 \mathrm{~h}$ in NYSM at $28^{\circ} \mathrm{C}$ and $200 \mathrm{rpm}$ to carry out the dose dependence bioassays. Cultures $(600 \mathrm{ml})$ were centrifuged at $12,800 \mathrm{~g}$ for $30 \mathrm{~min}$, at $4^{\circ} \mathrm{C}$ (BR4i centrifuge Jouan), the cell pellets were frozen for $16 \mathrm{~h}$ and lyophilized for $18 \mathrm{~h}$ in Labconco model Lyphlock 18 freeze-dryer. Afterwards, the material was weighed for use in the bioassay. The required weight of powder for each dilution was taken up in $5 \mathrm{ml} \mathrm{0.01 \%} \mathrm{Tween} 20$ to achieve a more homogeneous suspension and this was added to $35 \mathrm{ml}$ of the artificial diet before it was poured out into petri dishes and was punched with 48 holes. Each hole received a neonate larva. During the experiment, five concentrations (from 0.10 to $1.5 \mathrm{mg} / \mathrm{ml}$ ) were tested and one bacteria free control was included. The bioassay was kept in an incubator with photoperiod of $14: 10$ at $27^{\circ} \mathrm{C}$. A week later, the bioassay was read and the $\mathrm{LC}_{50}$ was determined through probit analysis (Finney, 1971). B. thuringiensis subsp. tenebrionis T08 017 was obtained from the Collection of Bacillus thuringiensis and Bacillus sphaericus at the Institut Pasteur, Paris and was used as the reference of coleopteran-active isolate (Hofte et al., 1987). The bioassay was repeated three times and the $\mathrm{LC}_{50}$ were compared by ANOVA through Sigmastat program (Kuo et al., 1992).

The protein profiles of the isolates that showed the best toxicity were analyzed by SDS-PAGE in 10\% acrylamide gels. The proteins were extracted from the culture according 
to Lecadet et al. (1991) and $15 \mu$ of each sample was loaded on the gel. After electrophoresis, the gel was stained and fixed in $40 \%$ methanol, $10 \%$ acetic acid and Coomassie blue $(0.1 \%)$ for about $16 \mathrm{~h}$, under slight shaking and destained in $40 \%$ methanol and $10 \%$ acetic acid for $2 \mathrm{~h}$ with agitation. $B$. thuringiensis subsp. tenebrionis T08017 was again used as the reference isolate.

The molecular characterization was performed through PCR to identify the toxin-coding genes, by using a variety of oligonucleotide pairs able to amplify the following genes/gene families: cry1, cry2, cry3 , cry4, cry8, cry9, cry10, cry11, cyt1 and cyt2 (Ceron et al., 1994, 1995; Bravo et al., 1998; Ibarra et al., 2003). The extraction methodology for DNA was described by Sambrook et al. (2001).

Isolate S1806 was serotyped according to de Barjac (1981) using H-specific antisera kindly provided by Institut Pasteur.

\section{Results and discussion}

Among the 215 isolates examined, 5 produced greater than $50 \%$ larval mortality in the selective assay and were selected for the dose-dependence bioassay. From the $\mathrm{LC}_{50}$ results, four statistically different groups could be seen among the isolates evaluated (ANOVA $\mathrm{H}=16.62 ; 6$ d.f.; $p=0.011$ ) (Table 1). The S601 isolate was classified as belonging to group $\mathrm{A}$ and showed the best $\mathrm{LC}_{50}$ result, which was $0.15 \mathrm{mg} / \mathrm{ml}$. The reference isolate (B. thuringiensis subsp. tenebrionis) and S1806 were classified as belonging to group $B$ with $\mathrm{LC}_{50}$ of 0.32 and $0.30 \mathrm{mg} / \mathrm{ml}$, respectively, showing no statistical difference between the two isolates. Group C contained only one isolate, B. thuringiensis subsp. israelensis IPS82 obtained from the Collection of Bacillus thuringiensis and Bacillus sphaericus Meyer and Neide at the Institut Pasteur, Paris, which is a standard isolate active against the dipteran order, presenting a $\mathrm{LC}_{50}$ of $0.74 \mathrm{mg} / \mathrm{ml}$ against $A$. grandis. The other isolates, $\mathrm{S} 811$, S785 and S 325 were classified as belonging to group D, showing $\mathrm{LC}_{50}$ of $1.5,3.5$ and $8.1 \mathrm{mg} / \mathrm{ml}$ (Table 1) respectively.

The group A isolate $\mathrm{S} 601$ produced a major $130 \mathrm{kDa}$ protein and four other proteins of lower molecular mass (Fig. 1). This major protein is consistent with the presence

Table 1

Toxicity of Bacillus thuringiensis (Bt) isolates against Anthonomus grandis

\begin{tabular}{|c|c|}
\hline Strain & $\mathrm{LC}_{50}(\mathrm{mg} / \mathrm{ml})^{\mathrm{a}}$ \\
\hline S601 & $0.14(0.11-0.17) \mathrm{A}$ \\
\hline S1806 & $0.30(0.25-0.36) \mathrm{B}$ \\
\hline Bt subsp. tenebrionis ${ }^{\mathrm{b}}$ & $0.32(0.23-0.44) \mathrm{B}$ \\
\hline Bt subsp. israelensis & $0.74(0.61-0.91) \mathrm{C}$ \\
\hline S811 & $1.5(0.97-2.9) \mathrm{D}$ \\
\hline S785 & $3.5(1.8-16) \mathrm{D}$ \\
\hline S325 & $8.1(2.9-16.) \mathrm{D}$ \\
\hline
\end{tabular}

${ }^{\mathrm{a}} \mathrm{LC}_{50}$ values are shown (with confidence limits at a level of $95 \%$ ). Different uppercase letters indicate significant differences between $\mathrm{LC}_{50}$ values.

b Reference for coleopteran toxicity.

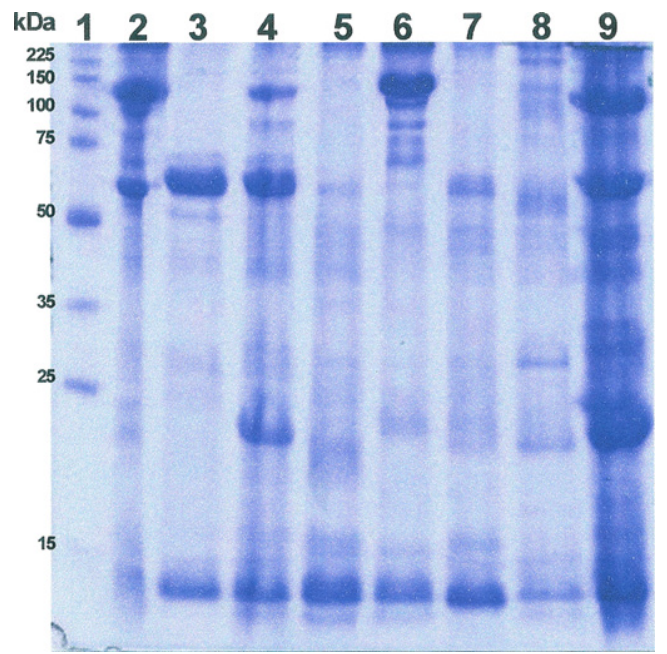

Fig. 1. SDS-PAGE of Bacillus thuringiensis crystal proteins from the selected isolates. Spore/crystal preparations from sporulated cultures were subjected to electrophoresis in 10 acrylamide gels. $\mathrm{M}$, rainbow molecular weight markers (Amersham), 1, B. thuringiensis subsp. tenebrionis, 2, B. thuringiensis subsp. israelensis, 3, S325, 4, S601, 5, S785, 6, S811 and 7, S1806.

Table 2

Profile of cry genes/families in the selected Bacillus thuringiensis (Bt) isolates determined by PCR

\begin{tabular}{ll}
\hline Isolate & Genes/gene families \\
\hline S601 & cry1B \\
S1806 & cry $4 A$, cry $4 B$, cry10, cry11, cyt 1 \\
Bt subsp. tenebrionis & cry $3 A$, cry8 \\
Bt subsp. israelensis & cry $4 A$, cry $4 B$, cry10, cry11, cyt 1 \\
S811 & cry1 Ab, cry 1I,cry 8 \\
S785 & cry2 \\
S325 & cry2 \\
\hline
\end{tabular}

of the $\operatorname{cryl} B$ gene that was detected by PCR analysis (Table 2 ) and the product of which was previously described to be toxic to coleopteran insects (Brizzard and Whiteley, 1988). It is possible that the toxicity of S601 is due to the presence of this protein.

The group B isolate S1806 was serotyped as a subsp. israelensis isolate and exhibited a protein profile (Fig. 1) and cry genes similar to B. thuringiensis subsp. israelensis IPS82 (Table 2). S1806 presented the same level of toxicity as $B$. thuringiensis subsp. tenebrionis showing that the mosquitocidal isolate S1806 (unpublished data) could also be toxic to coleopteran larvae. This result reflects a previous study demonstrating $B$. thuringiensis subsp. israelensis isolate activities against insects of the coleopteran order (Méndez-López et al., 2003). The standard B. thuringiensis subsp. israelensis isolate also exhibited high level toxicity, albeit of a lower level than S1806.

S811 produced major proteins of 130 and $65 \mathrm{kDa}$ (Fig. 1) consistent with the crylAb, crylI and cry 8 genes detected by PCR (Table 2). Cry1I and Cry8 have been described as toxic to coleopteran larvae (Tailor et al., 1992; Abad et al., 2001). S785 and S325 presented a $65 \mathrm{kDa}$ protein (Fig. 1) consistent with the presence of a cry2 gene (Table 2). 
The Cry2 protein has not previously been described as showing toxicity to coleopteran larvae. However, none of the isolates showed PCR amplicons for the cry3 gene, the product of which has been described previously as active against Coleoptera (Bravo et al., 1998).

These analyses prove the utility of the boll weevil bioassay described and indicate its potential to select native $B$. thuringiensis isolates that may be used either directly in the biological control of boll weevil or as the source of genes to produce transgenic cotton plants resistant to this insect.

\section{References}

Abad, A.R., Duck, N.B., Feng, X., Flannagan, R.D., Kahn, T.W., Sims, L.E., 2001. Genes encoding novel proteins with pesticidal activity against coleopterans. Patent: WO 0234774-A 02-MAY-2001; E.I. Du Pont De Nemours AND COMPANY (US).

Baum, J.A., Light Mettus, A.-M., 2000. Polypeptide compositions toxic to Diabrotica insects, obtained from Bacillus thuringiensis; CryET70, and methods of use. Patent: PCT WO/00/26378-B 11-MAY-2000. Monsanto Company; 700 Chesterfield Parkway North, GG4C; Plant Protection; St. Louis, MO, USA.

Baum, J.A., Chu, C., Rupar, M., Brown, G., Donovan, W., Huessing, J., Ilagan, O., Malvar, T., Pleau, M., Walters, M., Vaughn, T., 2004. Binary toxins from Bacillus thuringiensis active against the western corn rootworm, Diabrotica virgifera virgifera LeConte. Appl. Environ. Microbiol. 70, 4889-4898.

Bravo, A., Sarabia, S., Lopez, L., Ontiveros, H., Abarca, C., Ortiz, A., Ortiz, M., Lina, L., Villalobos, F.J., Peña, G., Nuñez-Valdez, M.E., Soberón, M., Quintero, R., 1998. Characterization of cry genes in a Mexican Bacillus thuringiensis strain collection. Appl. Environ. Microbiol. 64, 4965-4972.

Brizzard, B.L., Whiteley, H.R., 1988. Nucleotide sequence of an additional crystal protein gene cloned from Bacillus thuringiensis subsp. thuringiensis. Nucl. Acids Res. 16, 2723-2724.

Busoli, A.C., Soares, J.J., Lara, F.M., 1994. O bicudo do algodoeiro e seu manejo. FUNEP, Jaboticabal: . 32 p. (Boletim, 5).

Ceron, J., Covarrubias, L., Quintero, R., Ortiz, A., Ortiz, M., Aranda, E., Lina, L., Bravo, A., 1994. PCR analysis of the cryI insecticidal crystal family genes from Bacillus thuringiensis. Appl. Environ. Microbiol. 60, $353-356$.

Ceron, J., Ortiz, A., Quintero, R., Guereca, L., Bravo, A., 1995. Specific PCR primers directed to identify cryI and cryIII genes within a Bacillus thuringiensis strain collection. Appl. Environ. Microbiol. 61, 3826-3831.

Crickmore, N., Zeigler, D.R., Feitelson, J., Schnepf, E., Van Rie, J., Lereclus, D., Baum, J., Dean, D.H., 1998. Revision of the nomenclature for the Bacillus thuringiensis pesticidal crystal proteins. Microbiol. Molec. Biol. Rev. 62, 807-813.

de Barjac, H., 1981. Identification of H-serotypes of Bacillus thuringiensis. In: Burges, H. (Ed.), Microbial Control of Pests and Plants Diseases 1970-1980. Academic Press, London, pp. 35-43.

Feitelson, J.S., Payne, J., Kim, L., 1992. Bacillus thuringiensis insects and beyond. Biotechnology 10, 271-275.

Finney, D., 1971. Probit Analysis. Cambridge University Press, Cambridge, UK.

Gallo, D., Nakano, O., Silveira Neto, S., Carvalho, R.P.L., De Baptista, G.C., Berti Filho, E., Parra, J.R.P., Zucchi, R.A., Alves, S.B., Vendar- min, J.D., Marchini, L.C., Lopes, J.R.S., Omoto, C., 2002. Entomol. agrícola. FEALQ, Piracicaba, p. 920.

Hofte, H., Seurinck, J., Van Houtven, A., Vaeck, M., 1987. Nucleotide sequence of a gene encoding an insecticidal protein of Bacillus thuringiensis var. tenebrionis toxic against Coleoptera. Nucleic Acids Res. 15, 7183.

Ibarra, J., Rincon, C., Ordúz, S., Benintende, G., Monnerat, R., Regis, L., Sánchez, J., Bravo, A., 2003. Diversity of Bacillus thuringiensis strains from Latin America with insecticidal activity against different mosquitoes species. Appl. Environ. Microbiol. 69, 5269-5274.

Kuo, J., Fox, E., MacDonald, S., 1992. Sigmastat: statistical software for working scientists. Users manual. Jandel Scientific, San Francisco, CA.

Lecadet, M.M., Chaufaux, J., Ribier, J., Lereclus, D., 1991. Construction of novel Bacillus thuringiensis strain with different insecticidal activities by transduction and transformation. Appl. Environ. Microbiol. 58, $840-849$

Luttrell, R.G., Fitt, G.P., Ramalho, F.S., Sugonyaev, E.S., 1994. Cotton pest management: Part 1. A worldwide perspective. Annu. Rev. Entomol. 39, 517-526.

Martin, D.F., Barbosa, S., Campanhola, C., 1987. Observações preliminares e comentário sobre o bicudo do algodoeiro, no Estado de São Paulo. Jaguariúna, EMBRAPA-CNPDA. 21 p. (EMBRAPA-CNPDA, Circular Técnica, 1).

Méndez-López, I., Basurto-Ríos, R., Ibarra, J., 2003. Bacillus thuringiensis serovar israelensis is highly toxic to the coffee berry borer, Hypothenemus hampei Ferr. (Coleoptera: Scolytidae). FEMS Microbiol. Lett. 226, 73-77.

Monnerat, R.G., Silva, S.F., Silva-Werneck, J.O., 2001. Catalogo do Banco de germoplasma de bactérias entomopatogênicas do gênero Bacillus. Brasília: Embrapa Recursos Genéticos e Biotecnologia, 65 p.

Pallini, A., Silvie, P., Monnerat, R.G., Ramalho, F.F.S., Songa, J.M., Birch, A.N.E., 2006. Non-target and biodiversity impacts on parasitoids. In: Hilbeck, A., Andow, D.A., Fontes, E.M.G. (Eds.), Environmental Risk Assessment of Genetically Modified Organisms volume 2: Methodologies for Assessing Bt Cotton in Brazil. first ed., CABI Publishing, Wallingford, UK, pp. 200-224.

Ponchio, L.A., 2001. Paridade de preços nos mercados nacional e internacional do algodão e a competitividade da cotonicultura brasileira. Tese de Graduação. ESALQ, Piracicaba, 48 p.

Praça, L.B., Martins, E.S., Gomes, A.C.M.M., Falcão, R., Monnerat, R.G., 2004. Prospecção de estirpes de Bacillus thuringiensis efetivas contra insetos das ordens Lepdoptera, Coleoptera e Díptera. Pesquisa Agropecuária Brasileira 39, 11-16.

Sambrook, J., Fritsch, E.F., Maniatis, T., 2001. Molecular Cloning: A Laboratory Manual, Third ed. Cold Spring Harbor Laboratory Press, Cold Spring Harbor, NY.

Santos, R.C., Marcellino, L.H., Monnerat, R.G., Gander, E.G., 2003. Mechanical damage in cotton buds caused by the boll weevil. Pesquisa Agropecuária Brasileira 38, 1351-1355.

Silvie, P., Leroy,T., Belot, J,L., Michel, B., 2001. Manual de identificação das pragas, e seus danos no algodoeiro. 1st ed. Cascavel: COODETEC/ CIRADCA, 2001.74 p. (B.T.N. $\left.{ }^{\circ} 35\right)$.

Tailor, R., Tippet, J., Gibb, G., Pells, S., Pike, D., Jordan, L., Ely, S., 1992. Identification and characterization of a novel Bacillus thuringiensis delta-endotoxin entomocidal to coleopteran and lepidopteran larvae. Mol. Microbiol. 6, 1211-1217.

Wolfenberger, D.A., Hamed, A.A., Luttrell, R.G., 1997. Toxicity of Bacillus thuringiensis against the boll weevil Anthonomus grandis Boh. (Coleoptera, Curculionidae). Beltsville Cotton Conf., 1296-1300.

Yousten, A.A., 1984. Bacillus sphaericus: Microbiological factors related to its potential as a mosquito larvicide. Adv. Biotechnol. Proc. 3, 315-343. 